\title{
Sustainable intensification of agriculture for human prosperity and global sustainability
}

\author{
Johan Rockström, John Williams, Gretchen Daily, Andrew Noble, Nathanial Matthews, \\ Line Gordon, Hanna Wetterstrand, Fabrice DeClerck, Mihir Shah, Pasquale Steduto, \\ Charlotte de Fraiture, Nuhu Hatibu, Olcay Unver, Jeremy Bird, Lindiwe Sibanda, \\ Jimmy Smith
}

Received: 13 October 2015/Revised: 6 March 2016/Accepted: 13 May 2016/Published online: 12 July 2016

\begin{abstract}
There is an ongoing debate on what constitutes sustainable intensification of agriculture (SIA). In this paper, we propose that a paradigm for sustainable intensification can be defined and translated into an operational framework for agricultural development. We argue that this paradigm must now be defined—at all scales—in the context of rapidly rising global environmental changes in the Anthropocene, while focusing on eradicating poverty and hunger and contributing to human wellbeing. The criteria and approach we propose, for a paradigm shift towards sustainable intensification of agriculture, integrates the dual and interdependent goals of using sustainable practices to meet rising human needs while contributing to resilience and sustainability of landscapes, the biosphere, and the Earth system. Both of these, in turn, are required to sustain the future viability of agriculture. This paradigm shift aims at repositioning world agriculture from its current role as the world's single largest driver of global environmental change, to becoming a key contributor of a global transition to a sustainable world within a safe operating space on Earth.
\end{abstract}

Keywords Agriculture development - Anthropocene . Global sustainability · Livelihoods · Resilience · Sustainable intensification

\section{INTRODUCTION}

A global food revolution based on a new paradigm for agricultural development is urgently required. Without this shift, we are unlikely to attain the twin objectives of feeding humanity and living within boundaries of biophysical processes that define the safe operating space of a stable and resilient Earth system (Steffen et al. 2015b). Global sustainability is increasingly understood as a prerequisite to attain human development (UN GSP 2012) at all scales, from local farming communities to cities, nations, and the world (Folke et al. 2005). The reason is that we have entered a new geological epoch, the Anthropocene, where human pressures are causing rising global environmental risks and for the first time constitute the largest driver of planetary change (Steffen et al. 2007, 2015b). Agriculture is at the heart of this challenge. It is the world's single largest driver of global environmental change (Tilman et al. 2001; Foley et al. 2005; Godfray and Garnett 2014; Kuyper and Struik 2014) and, at the same time, is most affected by these changes (IPCC 2014). Agriculture is the key to attaining the UN Sustainable Development Goals of eradicating hunger and securing food for a growing world population of 9-10 billion by 2050 , which may require an increase in global food production of between 60 and $110 \%$ (Foley et al. 2005; IAASTD 2008; Tilman et al. 2011; Pardey et al. 2014) in a world of rising global environmental risks. Agriculture is also the direct livelihood of 2.5 billion smallholder farmers (FAO 2013a), and the resilience of these livelihoods to rising shocks and stresses is currently gravely under-addressed (FAO 2013b).

Together, these insights provide a strong scientific justification for a shift from our current paradigm for agriculture of focusing on productivity first and sustainability as a question of reducing environmental impacts, to a paradigm where sustainability constitutes the core strategy for agricultural development. The planetary boundary definition of a safe operating space for a stable and resilient Earth system provides an operational framework for defining what constitutes sustainable agriculture. It has been proposed (Keating et al. 2014) that the "safe operating space" exploration of food security (Beddington et al. 2012), based on these principles (Rockström et al. 2009), analytically frames the problem and describes the interconnected forces of 
population growth, consumption growth, environmental change, and food security.

The definition of a biophysical safe operating space of the Earth system, within which it has a high likelihood of remaining in a stable inter-glacial state, emerges from the advancements in Earth system science over the past decades, providing evidence of interactions, feedbacks, and thresholds among environmental processes that regulate the Earth system (Lenton et al. 2008), and the conclusion that humanity has entered a new geological Epoch, the Anthropocene (Waters et al. 2016), where the world constitutes the largest driver of change on Earth.

Therefore, in the Anthropocene, humanity faces the imperative question of how to transform agriculture that feeds the world, contributes to eradicate poverty, and contributes to a stable planet. Given the decisive role of world agriculture on human development and on Earth system processes, we argue in this paper that sustainable agriculture is the only strategy that can deliver productivity enhancements to meet rising food needs and enable an Earth system operating within planetary boundaries.

There is a well-documented debate (Garnett and Godfray 2012; Kuyper and Struik 2014) on what constitutes sustainable intensification of agriculture (SIA) (Garnett et al. 2013; Godfray and Garnett 2014; Struik et al. 2014), its evolution (Kuyper and Struik 2014; Struik et al. 2014), and its role in addressing global food security (van Noordwijk and Brussaard 2014).

Here, SIA is largely on how to enhance agricultural productivity while reducing its environmental impacts (Conway 1997; Godfray and Garnett 2014; Kuyper and Struik 2014). The task is how to produce more food with fewer resources. Sustainable intensification, in this context, seeks to increase agricultural output while keeping the ecological footprint as small as possible. This is, in no doubt, a useful and relatively important feature of sustainable agriculture, particularly as mainstream agriculture development still concentrates on productivity and places limited focus on sustainability. It remains focused though on avenues for resource efficiency, e.g., based on assumptions that efficiency in water and fertilizer use represents the avenues towards sustainable agriculture. Particularly in agricultural development in povertystricken regions, this "productivity first" paradigm, while potentially reducing environmental impacts, prevails.

There is an urgent need to shift this around and instead use sustainable principles as the entry point for generating productivity enhancements, which fundamentally requires real progress in increasing agricultural output by capitalizing on ecological processes in agro-ecosystems (Struik et al. 2014; van Noordwijk and Brussaard 2014). This can be achieved by managing farmers' fields, watersheds, landscapes, and regions using strategies and practices that maintain biophysical stability and uphold critical feedbacks, such as moisture feedback from forests generating downwind rainfall (Gordon et al. 2008) and carbon sinks in soils and biomass (Le Quéré et al. 2015).

Incorporating ecological landscape approaches that make smart use of the natural functionalities that ecosystems offer is now an important part of the development of sustainable intensification of agriculture. The aim is to design multi-functional agro-ecosystems that are both sustained by nature and sustainable in their nature (Tittonell 2014).

In this paper, we propose that a new paradigm for SIA can be quantitatively defined from scientific advancements of the Anthropocene and biosphere resilience and translated into an operational framework for agricultural development. At its foundation, the new paradigm recognizes that the biophysical boundaries of Planet Earth impose a hierarchy of criteria on the definition of sustainability: sustainability is not a relative concept or an act of balancing competing claims; it sets absolute biophysical limits. It is only within such biophysically defined boundaries, such as operating within a $1.5^{\circ} \mathrm{C}$ global carbon budget or within environmental water flows for river basins, which - as far as our current scientific knowledge shows - we stand a high probability of avoiding irreversible shifts in environmental conditions. The planetary boundary analysis sets the boundary for a stable climate system at $350 \mathrm{ppm}$ of $\mathrm{CO}_{2}$ (uncertainty range of $350-450 \mathrm{ppm}$ ) or maximum $1 \mathrm{~W} / \mathrm{m}^{2}$ of climate forcing (uncertainty range $1-1.5 \mathrm{~W} / \mathrm{m}^{2}$ ), which translates to an average global temperature rise of approximately $1.5^{\circ} \mathrm{C}$ (Rogelj et al. 2015; Steffen et al. 2015a). As has been suggested, only by defining development within such technically defined criteria or boundaries, social and economic trade-offs can be assessed (Fischer et al. 2007). Recent works (Jackson et al. 2012; Tittonell 2014; van Noordwijk and Brussaard 2014) signal mechanisms and demonstrate principles that suggest that such a transformative approach to SIA is possible and this paper presents examples of ways forward.

We suggest adding a new dimension to sustainable agricultural development, namely managing natural capital for long-term productivity and social-ecological resilience at field, watershed, and regional scales, in agricultural systems that operate within planetary boundaries to safeguard Earth system.

Our approach builds on existing research and the current evolution of the frameworks for SIA giving further emphasis to land-use planning and management of natural capital in both agro-ecosystems and natural ecosystems across scales. A resilience (capacity to deal with shocks and stress) and Earth system (in the Anthropocene) focus is key to deal with a rising frequency of multiple shocks triggered by regional and global changes unprecedented in human history.

Furthermore, such a comprehensive sustainability paradigm, which not only minimizes environmental impacts but also uses sustainability as the strategy to raise productivity, 
improve livelihoods, and build resilience and Earth system stability, must meet the dramatic rise in food requirements from a world population of nearly 10 billion by 2050 , which most likely will reach 11 billion by the end of the century (Gerland et al. 2014). Together, these challengesthe social dimension of meeting rapidly rising food requirements and the ecological dimension of building agricultural resilience and Earth system stability-form a social-ecological framework for sustainable intensification of world agriculture (Jackson et al. 2012).

The criteria and approach we propose, for a paradigm shift towards SIA, integrates the dual and interdependent goals of using sustainable practices to meet rising human needs while contributing to resilience and sustainability across scales. Both of these, in turn, are required to sustain the future viability of agriculture. This paradigm shift aims at repositioning world agriculture from its current role as the world's single largest driver of global environmental change, to becoming a critical agent of a world transition to global sustainability within the biophysical safe operating space on Earth.

A transformation to sustainable intensification is thus justified both by necessity (to safeguard global sustainability, a precondition for long-term agricultural viability) and by opportunity (to use sustainable practices as a vehicle for a second green revolution).

\section{BACKGROUND}

\section{The necessity of a transformation of sustainable intensification of agriculture}

The case for intensification has been well articulated in the literature, both from a perspective of increased production, through high-yielding crops, increased irrigation, mechanization, and the role of chemicals that increase production levels (World Bank 2007), and from a conservation perspective, in terms of the millions of hectares of forests which otherwise would be converted into farm land, unquantifiable amount of ecosystem services saved, and of some 590 billion tons of $\mathrm{CO}_{2}$ prevented from being released into the atmosphere (Burney et al. 2010). We however underline the fact that much of such intensification has taken place with production increases being the primary, if not the sole, objective, whose negative consequences were understood after-the-fact and are now well documented.

Convincing evidence has emerged that humanity has entered the Anthropocene, where human pressures have reached a planetary scale in terms of ecosystem and resource constraints and rising risks of environmental shocks and large-scale tipping points (Lenton et al. 2008; Rockström et al. 2014; Steffen et al. 2015a; Waters et al. 2016). A rapid world transformation to global sustainability is increasingly acknowledged as necessary to enable human development within a functioning and healthy environment.

Agriculture is a primary driver of global change and is the single largest contributor to the rising environmental risks of the Anthropocene (Foley et al. 2011; Steffen et al. 2011; Struik et al. 2014). It is also in the Anthropocene that the challenge of feeding humanity needs to be resolved. The number of hungry people in the world remains at approximately 900 million (FAO, Ifad and WFP. 2013). At the same time, with rising living standards of the growing middle class, diets are shifting towards more livestock products that require more land and water resources than vegetarian sources of nutrition. In order to feed the world in 2050, global food production may have to increase by $60-110 \%$ (Pretty 2008; IAASTD 2008; Tilman et al. 2011; Ray et al. 2013; Pardey et al. 2014). The challenge is further complicated by the need not only to produce more, but also to manage the entire food supply chain much more efficiently, reducing waste which has reached unacceptable proportions (estimated at 30\%) along with promoting better distribution, access, and nutrition (FAO 2011a). This requires nothing less than a planetary food revolution which, for the foreseeable future, will largely be driven by the 2.5 billion smallholders that control 500 million small farms and which provide up to $80 \%$ of the food supply in Asia and sub-Saharan Africa (FAO 2012) while residing in some of the world's most social-ecologically vulnerable regions.

Today, approximately $40 \%$ of the world's terrestrial surface has been transformed to agriculture (crop, fiber, biofuel, and livestock production systems) (Ramankutty et al. 2008). Appropriate land for food production, however, is a finite resource and hence further expansion could compromise development within Earth's safe operating space (approximately $25 \%$ of anthropogenic emissions of greenhouse gases are sequestered on land, of which all occurs in terrestrial noncultivated ecosystems). If business-as-usual prevails, the expected range of cropland expansion (123-495 Mha per annum) would overshoot the preliminary estimate of the "safe operating space" of 1640 Mha well before 2050 (UNEP 2014).

Sustainable intensification of agriculture, in our proposed paradigm, aims at hunger reduction through biodiversity conservation that secures ecological functions in agricultural landscapes. It will require well-informed regional and targeted solutions (Tscharntke et al. 2012) drawing upon the strengths of both land-sparing and land-sharing approaches underpinned by strategic land-use planning and allocation (Law et al. 2015) across local, regional, and basin scales. Fischer et al. (2008) conclude that land sparing is readily compatible with optimization methods that attempt to allocate land uses in the most efficient way, while sustainable agro-ecological systems emphasize heterogeneity, resilience, and ecological interactions between farmed and unfarmed areas. Both social and biophysical factors influence which approach is feasible or appropriate in a given landscape. Our approach in this paper seeks to draw 
upon the strengths of each approach, although the focus of this paper is on transforming agricultural systems into sustainable agro-ecological systems. As mentioned above, however, conservation measures including protected area habitats, areas comanaged with local communities, and indigenous reserves are all potentially viable sustainable intensification strategies (Phalan et al. 2011; Garnett et al. 2013).

Our current agricultural inputs are also a challenge. Agriculture is the single largest user of freshwater in the world, with $70 \%$ of the totally withdrawn water of almost $6000 \mathrm{~km}^{3}$ year $^{-1}$ being diverted for agriculture (Kabat 2013), which has resulted in approximately $25 \%$ of the world's major river basins no longer reaching the ocean (Comprehensive Assessment of Water Management in Agriculture 2007). Agriculture is the world's largest contributor to altering the global nitrogen and phosphorus cycles (Carpenter 2005). Anthropogenic uptake of $\mathrm{N}$ from the atmosphere (for industrial and intentional biological fixation of $\mathrm{N}$ ) today exceeds the natural global uptake of $\mathrm{N}$ for biomass growth (Galloway and Cowling 2002; Gruber and Galloway 2008) and currently at approximately $150 \mathrm{Tg} \mathrm{N}$ year $^{-1}$ the global uptake far exceeds the boundary value of 62-82 $\mathrm{Tg} \mathrm{N}_{\text {year }}{ }^{-1}$ (Steffen et al. 2015a).

Although the focus of this paper is on sustainability as the strategy for productive agriculture, it is recognized that a case for sustainable intensification must also tackle the challenge of improving the health and livelihoods of the 2.5 billion smallholder farmers who are the primary stewards of our natural resources. As highlighted in the Global Nutrition Report (IFPRI 2015), improving nutrition status reduces disease burdens, increases income, improves life expectancies, and provides a host of additional socioeconomic benefits to families and communities. These benefits are essential drivers of sustainable development. A key strategy is investing in food that is healthy for people and planet, where nutritional food, low in refined sugars, fats, and meat, can help combat malnourishment and obesity and reduce emissions of greenhouse gases and resource footprints (Tilman and Clark 2014; IFPRI 2015).

Together, these social-ecological pressures pose an unprecedented challenge for the global food system, and we can see no other pathway to resolve it other than adopting a paradigm of sustainable intensification, with a dual purpose of (i) enabling a step-change in productivity and resilience and (ii) averting unacceptable global environmental risks.

\section{The way forward: transforming sustainable intensification of agriculture}

Recent efforts in defining SIA (Royal Society 2009; Conway et al. 2010; Godfray et al. 2010; Rockström and Karlberg 2010; Tilman et al. 2011; Pretty et al. 2011; Garnett et al. 2013; Godfray and Garnett 2014) provide an emerging framework built around the simple principle whereby 'yields are increased without adverse environmental impact and without the cultivation of more land' (Royal Society 2009). Our conclusion is that these definitions are either not concrete enough or only partial. World agriculture must now meet social needs and fulfill sustainability criteria that enables food and all other agricultural ecosystem services (i.e., climate stabilization, flood control, support of mental health, nutrition, etc.) to be generated within a safe operating space of a stable and resilient Earth system, which in turn can be defined from Earth system science applying the planetary boundary framework (Table 1). This is a comprehensive definition of sustainable intensification of agriculture in the Anthropocene.

Recognizing the central role agriculture plays in determining and regulating Earth's resilience, and the sustainability criteria for agriculture (outlined in Table 1), there is a strong case for adopting sustainable intensification of agriculture as the strategy to meet twin objectives for people and the planet. The "human goal," adopted by the UN Sustainable Development Goals (SDGs) in 2015, is to eradicate hunger and poverty by 2030 (which will require $>50 \%$ increase in food production). The global sustainability goal (as defined by Table 1) is supported by the SDG goals and targets 2-Healthy food for all, 6-Sustainable freshwater, 12-Sustainable Consumption and Production, 13-Decarbonising climate system under $1.5-2{ }^{\circ} \mathrm{C}, 14-$ Sustainable oceans, and 15-Halt biodiversity loss) and can only be translated as the UN SDGs setting out to feed humanity this within a safe operating space of a stable and resilient Earth system. Together, these integrated goals will require a doubly green revolution (Conway 1997) within ambitious and absolute targets for sustainability: in principle (1) net zero emissions of greenhouse gases, (2) very low or zero expansion of agriculture into remaining natural ecosystems, while restoring others providing vital ecosystem services, (3) zero loss of biodiversity, (4) drastic reduction in excessive use of $\mathrm{N}$ and $\mathrm{P}$ (recycling nutrient flows), and (5) major improvement in water productivity and safeguarding of environmental water flows. These will require, among others, conducive legal and institutional frameworks, incentives, rights, infrastructure, and support services that farmers will need for implementation.

From these social-ecological criteria emerges a clear definition of sustainable intensification: adopting practices along the entire value chain of the global food system that meet rising needs for nutritious and healthy food through practices that build social-ecological resilience and enhance natural capital within the safe operating space of the Earth system.

\section{Nature-based solutions for sustainable intensification of agriculture to build prosperity and resilience}

Evidence increasingly shows that sustainable agricultural practices can raise productivity and meet sustainability 


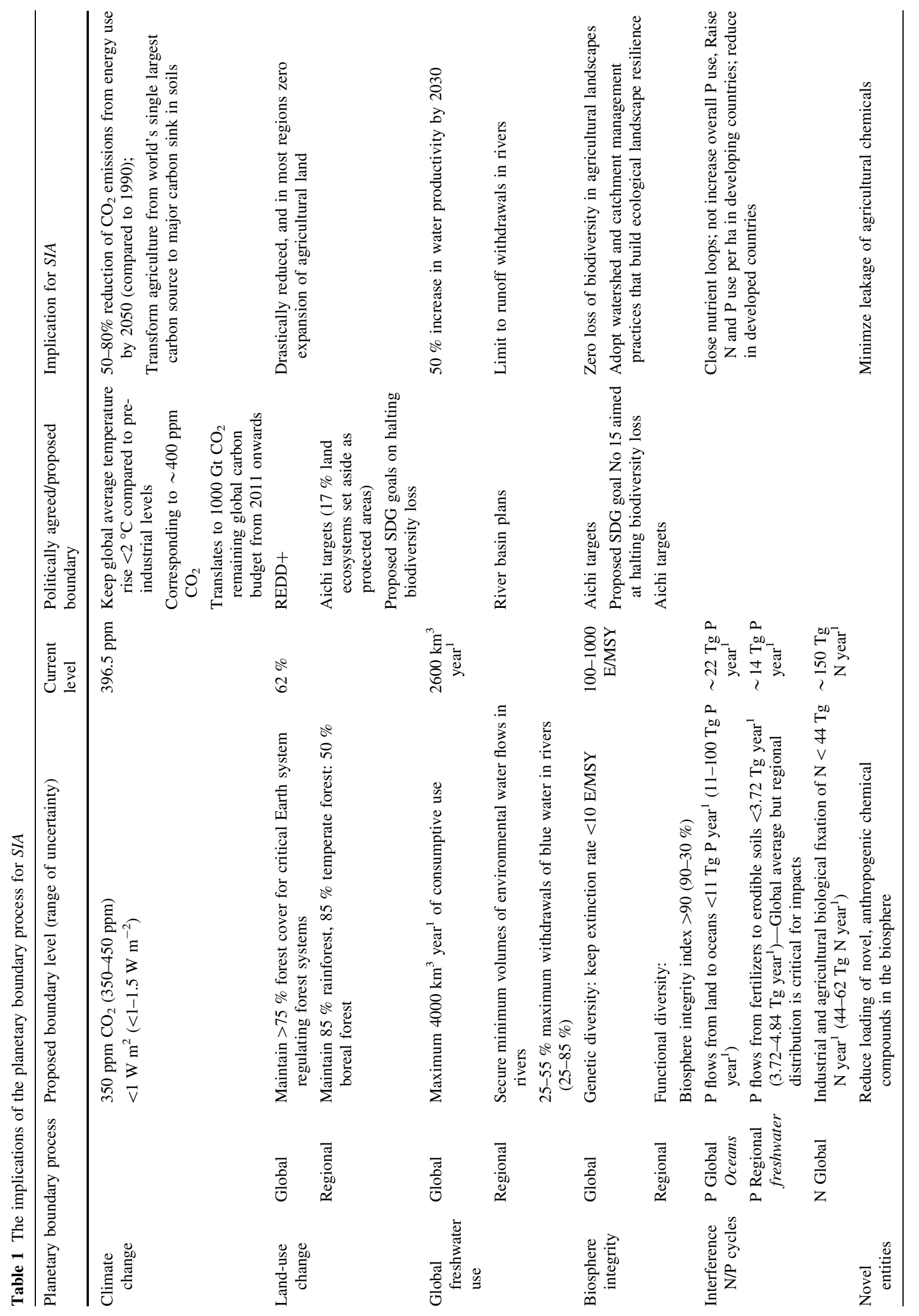


criteria (Pretty 2008; Royal Society 2009; Conway et al. 2010; Godfray et al. 2010; Rockström and Karlberg 2010; Tilman et al. 2011; Pretty et al. 2011; Garnett et al. 2013; Ponisio et al. 2015). A recent WRI report (2013) documents a worldwide range of sustainable management practices of land, water, and biodiversity in agro-ecosystems that increase productivity. A key part of the journey to long-term SIA requires safeguarding not only local (onfarm) productivity through sustainable practices, but also ecological functions across scales, from watershed, to basin, region, and Earth system scales, to avoid, e.g., loss of rainfall during future growing seasons. It furthermore requires building the capacity to deal with rising frequency and amplitude of shocks and stresses as a result of global changes (e.g., droughts and floods exacerbated by climate change; disease outbreaks promoted by globalization).

For example, with rising risks of water shocks at the local scale-droughts, floods, and dry spells, it is increasingly important to manage water across scales - from local farm fields to watersheds and river basins. Spatial planning strategies are required to safeguard multi-functional landscapes, with a diverse set of ecosystems that are able to dampen the effects of storm-floods and maximize sub-surface flows of water rather than erosive surface runoff. Wetlands, meandering rivers, forests, and landscape mosaics are important natural capital assets that build resilience. Moreover, watershed and river basin management is required to safeguard rainfall. In many parts of the world, a large portion of rainfall (often $>50 \%$ ) is convective, originating from local scale to meso-scale vapor flows, in particular from upwind evaporating forests contributing moisture flows that generate rainfall downwind. This socalled moisture feedback is common to the Sahel region where moisture from the West African rainforests in the south provides rainfall on the semi-arid savannah in the north. These examples demonstrate the importance of managing water at the watershed and regional scale in order to secure rainfall and therefore future food production at the local scale. This landscape approach needs to be nurtured and facilitated by a social-ecological framework for policy design and on-ground implementation (IAASTD 2008; Garnett et al. 2013; Godfray and Garnett 2014) (see Box 1).

SIA requires a radical refocusing of food production that encapsulates the twofold aims of increasing yields and the ecosystem services provided by agriculture (Godfray and Garnett 2014). In some areas, increases in yield will be compatible with environmental improvements. In others, yield reductions or land reallocation will be needed to ensure sustainability and deliver benefits such as biodiversity conservation, carbon storage, flood protection, and recreation (see Box 1). An overall increase in production does not mean that yields should increase everywhere or at any cost: the challenge is context and location specific.
Hence, SIA is about strategic land-use planning to maintain and improve the interacting stocks and flows involving water, nutrients, energy, carbon, and biodiversity across landscape mosaics of natural, semi-natural, and agricultural land uses, so that multi-functionality of the whole landscape is manageable across scales from local to basin to national levels.

From a production perspective (see Box 2), SIA should now entail a three-step approach: (1) at the basis be as resource efficient as possible combining locally relevant crop and animal genetic improvement and practices that minimize inputs and close nutrient, carbon, and water cycles, (2) adopt practices that build landscape-scale resilience by sustaining ecosystem functions and services, such as water flows and biodiversity, and (3) connect thinking, planning, and practice across scales to fully grasp field to biome and global interactions in the Anthropocene. This must go with improved and more equitable access to knowledge and resources including land tenure, common property, markets, and social relations. Building on the work of Pretty et al. (2011) and others (e.g., van Noordwijk and Brussaard 2014; Tittonell 2014), a paradigm shift towards SIA translates to some key operational strategies:

- Plan and implement farm-level practices in the context of cross-scale interactions with catchments, biomes, and the landscape as a whole. Maximize farm-level productivity by maximizing ecological functions, from moisture feedback to disease abatement, across scales.

- Integrate ecosystem-based strategies with practical farm practices, where natural capital (soil, biodiversity, nutrients, water) and multi-functional ecosystems are used as tools to develop productive and resilient farming systems.

- Develop system-based farming practices that integrate land, water, nutrient, livestock, and crop management.

- Utilize crop varieties and livestock breeds with a high ratio of productivity to use of externally and internally derived inputs.

- Adopt circular approaches to managing natural resources (e.g., nutrient recycling) and mixing organic and inorganic sources of nutrients.

- Harness agro-ecological processes such as nutrient cycling, biological nitrogen fixation, allelopathy, predation, and parasitism.

- Assist farmers in overcoming immediate SIA adoption barriers and build incentives for their sustained adoption, rendering the ecological approach profitable in the long run (See Box 2).

- Build robust institutions of small farmers, led especially by women, which enable an equitable interface with both markets and government. 


\section{Box 1 China's dream: ecosystem function conservation areas}

China is experiencing some of the world's most extreme challenges of environment and human development. There is now open recognition, at the highest levels of government, that environmental security is vital to national security and economic prosperity (Daily et al. 2013). In the spring of 2013, the National Development and Reform Commission declared China's Dream: "to become the Ecological Civilization of the 21st Century." The backdrop to China's Dream is that ecologically vulnerable areas account for more than $60 \%$ of the country and cannot sustain current human impacts. Agricultural security —and ecological security more generally-is at high risk, with severe biodiversity loss, soil erosion, flooding, sandstorms, and water and air pollution. With the world's largest population (over 1.35 billion), the second largest land area, and the second largest economy, the stakes are high.

In support of China's Dream, leaders are fostering intense policy innovation, pioneering new mechanisms for achieving the twin goals of securing the environment and human wellbeing. What is learned in China will have relevance everywhere.

Ecosystem Function Conservation Areas (EFCAs) are a new system of zoning land so as to focus conservation and restoration in places with highest return-on-investment for public benefit, to halt and reverse degradation of vital ecosystems and their life-support services, especially to poor and vulnerable people (NRDC 2013; CCICED 2014). The zoning is also meant to help secure people from flooding, improve drinking and irrigation water supply, maintain efficient hydropower production, protect biodiversity, stabilize climate, reduce sand storms and soil loss, and create more sustainable agricultural systems (see below figure).

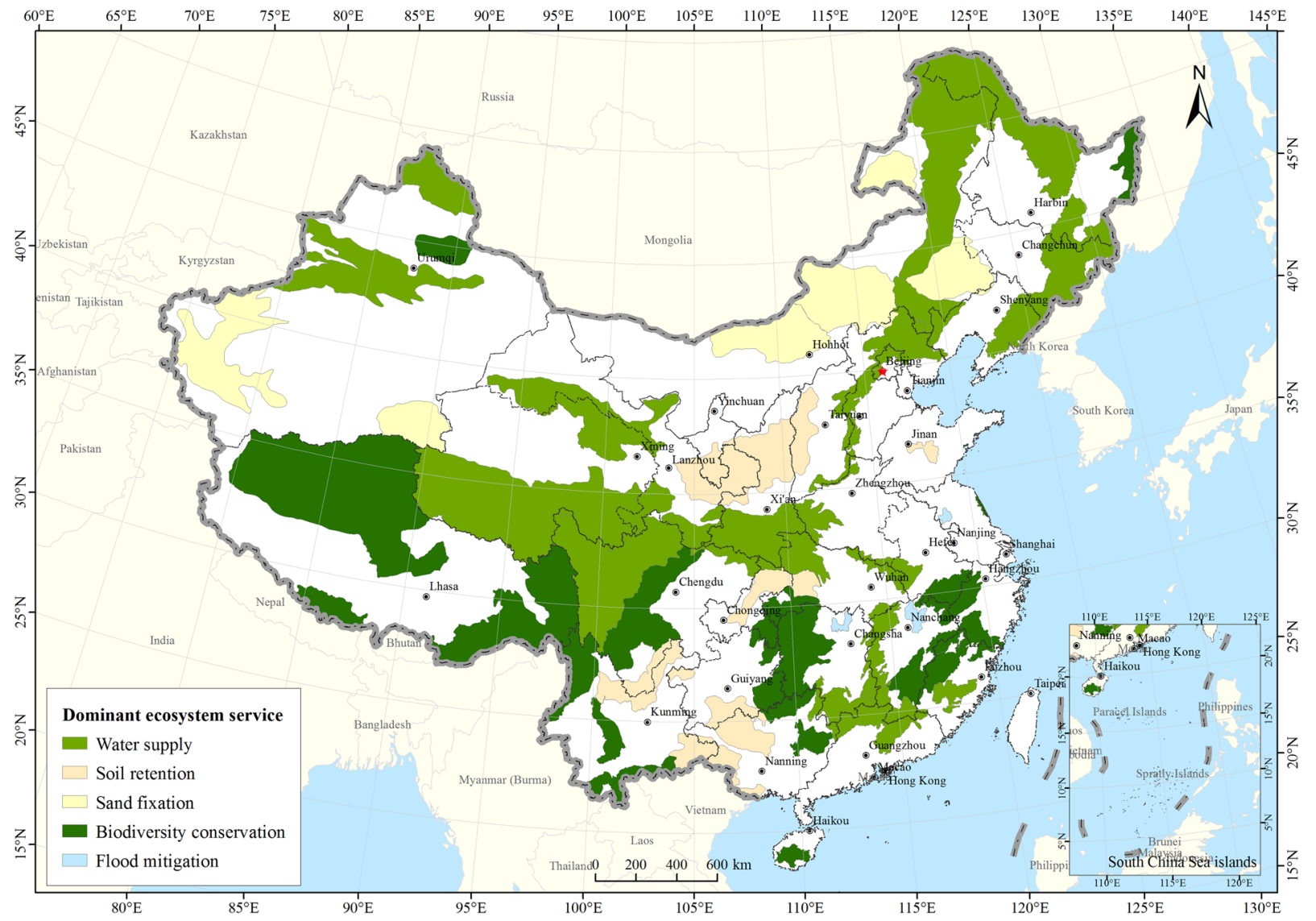

Figure showing China's new Ecosystem Function Conservation Areas (EFCAs), zoned to protect nationally critical biodiversity and ecosystem services, and to alleviate poverty, now span $49 \%$ of the country. The Natural Capital Project's InVEST models were codeveloped with the Chinese Academy of Sciences and are used to define the locations of EFCAs. China has invested over US $\$ 150$ billion in restoring natural capital since 2000, through a suite of pioneering initiatives. Now entering a new phase of investment, over 200 million people are being paid to perform restoration and conservation activities. Figure courtesy of H. Zheng and Z. Ouyang, Research Center for Eco-Environmental Sciences, Chinese Academy of Sciences (MEP \& CAS 1998; State Council of China 2010).

EFCAs are also a way of focusing poverty alleviation efforts in places where the stakes are highest, both for local residents and for distant beneficiaries of ecosystem services. EFCAs encompass rural areas in deep poverty that face great challenges in harmonizing people and nature. The government aims to change the economic structure of these regions to increase local household income while making local households' rural livelihoods more sustainable. 
Box 1 continued

Implementing EFCAs involves new, experimental compensation mechanisms, whereby regional beneficiaries-for example, Beijinginvest in the transformation to more sustainable livelihoods and improvements in wellbeing among the landholders producing the ecosystem services. EFCAs are expanding in both biophysical and financial terms. They spanned $27 \%$ of the country in $2008,40 \%$ in 2010, and grew to $49 \%$ of the country in 2015. Financial transfer payments increased from 6 billion Yuan RMB (to 221 counties) in 2008 to 48 billion Yuan RMB (to 512 counties) in 2014, for a total of 200 billion Yuan RMB (USD 32 billion) since inception.

While EFCA initiatives are driving massive scientific and policy shifts, there is still little understanding of their local costs of implementation, their success in reversing environmental degradation, or their effects on poor and vulnerable populations. The initiatives represent a new paradigm for integrating conservation and human development, in China and potentially elsewhere. Success hinges on careful testing, evaluation, and refinement.

Further, while the idea of a green GDP has been discussed for decades, China is the first nation to implement it. In March 2014, the Ministry of Environmental Protection of China approved reporting Gross Ecosystem Product (GEP) alongside Gross Domestic Product at all levels of government, from local to national. GEP is the total value of final ecosystem goods and services to human welfare, including production of agricultural goods, as well as generation of regulating services and cultural values (Ouyang et al. 2013). The objective of GEP accounting is to determine the total economic value of ecosystem contributions to human wellbeing, to build the links between ecosystem service providers and beneficiaries, and to assess the achievements of ecological protection and government management, instead of only GDP.

\section{Sustainable intensification can deliver more food, better ecosystems, and improved livelihoods}

Scientific and practical evidence clearly indicates that agriculture can shift from "foe," in terms of being the single large contributing sector to global environmental risks, to "friend," thereby contributing to global sustainability, and, in so doing, build natural capital and resilience, while increasing productivity and improving livelihoods (Pretty et al. 2006, Pretty 2008; IAASTD 2008; Foley et al. 2011; Pretty et al. 2011). The sources of sustainable practices range across all areas of agricultural development, in soil tillage systems, water resource management, crop and nutrient management, livestock practices, integrated landscape management, pest management, and management of ecosystem services are already evident and what is required is a scaling up. For example:

- The Comprehensive Assessment of Water Management in Agriculture (2007) showed that there is a large untapped potential in upgrading rainfed agriculture in savannah regions (covering $40 \%$ of the Earth's surface) by enhancing rainwater harvesting. As an example, in semi-arid areas of Niger and Burkina Faso, small-scale farmers use planting pits to harvest rain water and rehabilitate degraded land for the cultivation of millet and sorghum. In Burkina Faso alone, these practices have helped rehabilitate up to 300000 hectares of land and produce an additional 80000 tons of food per year (Reij et al. 2009). In addition, in southern Niger, farmers are innovatively regenerating and multiplying valuable trees on their lands, and this has improved about 5 million hectares while producing more than 500000 additional tons of food per year resulting in improved food security for about 3 million people. Other ecosystem benefits registered included reduced wind speed and evaporation (Reij et al. 2009), and incomes for women from different products of baobab up to $\$ 210$ per household per year.

- In Ethiopia, farmers capture flood water and runoff from ephemeral rivers, roadsides, and hillsides using temporary stone and earth embankments, to irrigate crops and pasture. In the central and western part of the country, total irrigated land is approximately 65500 ha, and some 344000 (approximately $90 \%$ ) of the households have benefited from doubling of sorghum yields as well as $75 \%$ sustainable expansion production of pepper, onions, and tomatoes (Binyam and Desale 2015). Other ecosystem benefits have included improved moisture and fertility in the cultivated fields and reduction of downstream flooding (Awulachew 2010; Liniger et al. 2011).

- In Brazil, conservation agriculture (CA) which is practiced on over 25 million ha (accounting for over $25.5 \%$ of arable land) is defeating erosion and drought. For example, severe drought in 2008-2009 caused an average yield loss of $50 \%$ among conventional maize producers; producers who applied CA, however, experienced smaller losses of around $20 \%$, demonstrating greater resilience of the latter system (Altieri et al. 2012).

- Too often, agro-ecosystems have been considered as separate from other natural ecosystems and insufficient attention has been paid to the way in which services can flow to and from the agro-ecosystem to surrounding ecosystems. Recent research (Poppy et al. 2014) illustrates that an ecosystem services approach to food security using a case study from the Zomba district of Malawi allows key issues in food security/environmental stability to be addressed, including scale, the identity of beneficiaries, trade-offs, and the winners and losers from management and mitigation strategies. The study illustrates the power of an ecosystem services approach to strategic land-use planning and implementation. 


\section{Box 2 Smart solar pumps: a potential solution to groundwater exploitation in India}

In Karnataka, southwest India, the local electric company is required to buy back surplus solar power from farmers-similar to programs in parts of Germany, Japan, and the United States. The buyback policy, signed by Karnataka's governor in September 2014, is consistent with recommendations to treat solar power as a 'cash crop.' The rationale is that if farmers can make money by selling excess power, they then will have an economic incentive to irrigate their crops efficiently, thus helping to conserve groundwater and energy use.

Despite inheriting the world's largest canal irrigation network built during British colonial rule, India has become the biggest groundwater irrigation economy, with nearly 20 million electric and diesel pumps irrigating more than 67 million hectares of land a year. Heavily subsidized pumps have driven groundwater depletion in western India and other parts of the country. An unreliable electric grid, bankrupted utilities, and power theft have contributed to the problem.

India's National Solar Mission, which aspires to develop 22 gigawatts of solar power by 2020, largely by constructing massive solar power plants. However, India could achieve its solar goal with 2 million solar irrigation pumps instead and "put cash in farmers' hands" in the process. The approach that is being promoted in Karnataka is presented. This approach of selling excess electricity back into the national grid could be used elsewhere in developing and emerging economies to drive significant decreases in $\mathrm{CO}_{2}$ emissions from fossil fuels used to pump groundwater, a shift to more sustainable utilization of groundwater, as well as enhanced food security.

\section{Selling Sunlight}

To support sustainable irrigation

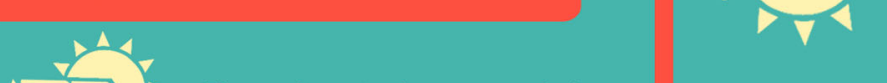

The number of solar pumps in India nearly tripled in 2013.

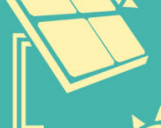

Groundwater
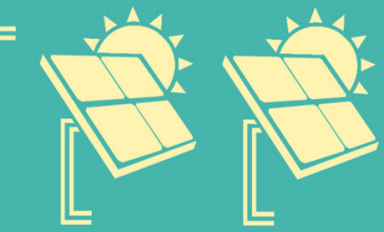

Solar power as a cash crop
Solar panels offer a cheap and

reliable way for farmers to extract

groundwater.

But, "free" power may lead to unrestricted pumping. depleting aquifers.

Farmers could potentially sell excess solar power to the national grid.

With targeted subsidies, the average farmer could benefit by up to $\$ 1,200$ per year.

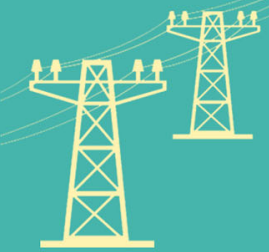

Solar can also lift the power economy up by freeing it from farm power subsidies.

\section{Carbon neutral irrigation}

21 million diesel and electric pumps produce

$15 \%$ of India's food.

$6 \%$ of it's total carbon emissions. $\mathrm{CO}_{2}$

Solar pumps could help reduce their

carbon footprint and boost food security.

The CGIAR Research Program on Water Land and Ecosystems (WLE) is researching the likely impact of solar powered groundwater pumping in India. Recommendations are already emerging to ensure that this technology promotes sustainable water extraction. There are promising signs that some Indian states are already adopting these approaches, and interest is growing at a national level.

Figure addressing the challenge of over-exploited groundwater reserves in India through the co-generation of power from solar panels for pump sets to pump water for irrigation and satisfy national energy requirements in India 
- Science and innovation that strengthens sustainability, while improving productivity and on-farm profits, is possible. Such systems have been developed in Australia (Williams and McKenzie 2008a, b) and elsewhere and have been adopted by grain growers who are moving increasingly to conservation farming techniques, such as no-till farming-improved agronomy through more sophisticated crop rotations to minimize nutrient leakage and maximize nutrient cycling, interfaced with integrated weed and pest management options that rely less on chemicals.

- In the southern Indian state of Andhra Pradesh, a million farmers have come together, in an FAO-supported project, to restore depleted groundwater tables, adopting an approach to governing the commons delineated by Nobel Laureate Elinor Ostrom (World Bank 2010). Food security is increased, utilizing ecosystem services, without exhausting the endangered resource.

- Rehabilitating degraded landscapes in the Highlands is a high-priority of the Ethiopian government and its partners. Research by CGIAR Centers and programs working with national partners has helped lay the groundwork. An ICRISAT-led activity is promoting integrated watershed management in the Yewol watershed in the Amhara Regional State, Ethiopia. By strengthening local capacity, facilitating collective action, using research to identify niches for integration of technologies at farm and landscape scales, and introducing system compatible technologies, the project has led to improved productivity, crop diversification, improved downstream water availability, and strengthened livelihoods for an estimated 15000 beneficiaries (Evaluation of WLE 2016, p. 52).

\section{CONCLUSIONS}

\section{Challenges for science}

Adopting a livelihood-centered paradigm for sustainable intensification within planetary boundaries is a major challenge for research and development that will require new approaches to how research for development is formulated, managed, and executed.

Pursuing SIA will entail approaches that integrate social and natural sciences, in solution-oriented knowledge generation that couples academic and practical knowledge through co-design and co-development of research. The implementation of SIA will require an understanding of the political economy in which food is traded and prices are determined and the business economy along the value chain from field to consumer. A major reason why farmers persist in growing water-intensive crops even in water-scarce regions is that State support for prices and procurement is limited to such crops and is not available for more ecologically appropriate crops such as pulses and millets. The result has been the emergence, for example of the "Punjab Water Syndrome," where falling water tables combine dangerously with waterlogging in other parts of the state in India (Kulkarni and Shah 2013). However, the aforementioned could be addressed through innovative incentivebased approaches that result in distinct behavior changes (see Box 2).

A lasting paradigm shift will require the ability to place research into policy and enable large-scale change. Influencing policy requires an understanding of the power dynamics and political systems that both enable and undermine the shift to SIA, associated improvements in livelihoods, and protection of the environment. Institutional trust will need to be built among the many stakeholders in the food system, all of whom will be required to make compromises. While SIA needs to be central to the way we produce food in the future, it also needs to be integrated within a nexus of strategies aimed at achieving food system sustainability, in the broadest sense of the phrase (Godfray and Garnett 2014).

\section{Grand experiments for transformation, co-design, and learning}

It should be recognized that SIA is a new, evolving concept, and its meaning and objectives subject to debate and contest. Sustainable intensification is only part of what is needed to improve food system viability and sustainability and is not synonymous with food security. Both sustainability and food security have multiple social, ethical, and environmental dimensions. Achieving a sustainable, health-enhancing food system for all will require more than just changes in agricultural production, essential though these are. Equally radical agendas will need to be pursued to reduce resource-intensive consumption and waste and to improve governance, e.g., on trade, incentives and equity. Much hope has been generated by India's 12th Five Year Plan, which adopts a paradigm shift in water resource management, exactly along the lines proposed in this paper (Shah 2013). A promising development is the emphasis in the strategic plan of the CGIAR until 2030 (CGIAR 2015), which places reduced poverty, improved food and nutrition security for health, and improved natural resources and ecosystem services, as its three highest level system outcomes. As the CGIAR played a pivotal role in the 1st Green Revolution, this creates the potential framework for a 2nd Green Revolution based on SIA principles.

Similarly, FAO pursues a strategic transformation, which endorses an ecosystem approach in agricultural 
management for sustainable crop production intensification, provides associated policy advice, and envisages a vision of sustainable food and agriculture that merges access by all to nutritious food with ecosystem-focused natural resources management (FAO 2011b, 2014).

The shift outlined in this article demands a new framework for research and development. Major productivity enhancements are required, and the strategy is through sustainable intensification of agricultural practices for livelihoods that build farm, community, and biosphere resilience. New research and development is required to advance fresh integrated whole-of-systems approaches for sustainable intensification, which can inspire and influence all domains involved in agricultural development, from economics to biotechnology.

We believe one strategy forward is the investment in spatially concentrated major "grand experiments" where knowledge from different domains, ranging from irrigated to rainfed agriculture, ecology and agronomy, equity to business development, work together to pilot sustainable intensification at scale (e.g., in a region or basin), to pool experience, explore synergies and trade-offs, testing the hypothesis that sustainable intensification can deliver food, livelihoods, and resilience, while contributing to development within Earth's safe operating space. These would be large $R \& D$ investments. They would deviate from the normal business-as-usual approaches of discipline by discipline, sector-by-sector, scale-by-scale approaches to agricultural development. They would be system-integrating and innovative ventures, and thus challenging but, as argued in this paper, necessary. Evidence strongly suggests that sustainable transformations of agricultural systems are direly and urgently required to meet World and Earth needs.

Acknowledgments We gratefully acknowledge the valuable contributions of WLE scientists in advancing sustainable intensification. We are grateful for the support from the Stockholm Resilience Centre, The CGIAR Research Program on Water, Land and Ecosystems and the Natural Capital Project. Special thanks to two anonymous reviewers for their comments on earlier drafts of this article and to the Editor and Springer Corrections team. We also thank Belinda Crozier for much appreciated assistance with formatting.

Open Access This article is distributed under the terms of the Creative Commons Attribution 4.0 International License (http:// creativecommons.org/licenses/by/4.0/), which permits unrestricted use, distribution, and reproduction in any medium, provided you give appropriate credit to the original author(s) and the source, provide a link to the Creative Commons license, and indicate if changes were made.

\section{REFERENCES}

Altieri, M.A., F.R. Funes-Monzote, and P. Petersen. 2012. Agroecologically efficient agricultural systems for smallholder farmers: contributions to food sovereignty. Agronomy for Sustainable Development 32: 1-13.
Awulachew, S.B. 2010. Irrigation potential in Ethiopia: constraints and opportunities for enhancing the system. Colombo: International Water Management Institute (IWMI).

Beddington, J., M. Asaduzzaman, M. Clark, A. Fernández, M. Guillou, M. Jahn, L. Erda, and T. Mamo, et al. 2012. Achieving food security in the face of climate change: Final report from the commission on sustainable agriculture and climate change. Copenhagen: CGIAR Research Program on Climate Change, Agriculture and Food Security (CCAFS). www.ccafs.cgiar.org/ commission.

Binyam, A.Y., and K.A. Desale. 2015. Rain water harvesting: An option for dry land agriculture in arid and semi-arid Ethiopia. International Journal of Water Resources and Environmental Engineering 7: 17-28.

Burney, J.A., S.J. Davis, and D.B. Lobell. 2010. Greenhouse gas mitigation by agricultural intensification. Proceedings of the National Academy of Sciences of the United States of America 107: 12052-12057.

Carpenter, S.R. 2005. Eutrophication of aquatic ecosystems: bistability and soil phosphorus. Proceedings of the National Academy of Sciences of the United States of America 102: 10002-10005.

CCICED (China Council for International Cooperation on Environment and Development). 2014. Institutional Innovation of EcoEnvironmental Redlining, CCICED Special Policy Study Report. CCICED 2014 Annual General Meeting 2014.12.1.

CGIAR. 2015. CGIAR strategy and results framework 2016-2030. Redefining How CGIAR does business until 2030. CGIAR Consortium Office.

Comprehensive Assessment of Water Management in Agriculture. 2007. In Water for food, water for life: A comprehensive assessment of water management in agriculture, ed. D. Molden. London: Earthscan, and Colombo: International Water Management Institute.

Conway, G. 1997. The doubly green revolution: Food for all in the twenty-first century. Ithaca, NY: Comstock Publishing Associates.

Conway, G., J. Waage, and S. Delaney. 2010. Science and innovation for development. London: UK Collaborative on Development Sciences.

Daily, G.C., O. Zhiyun, Z. Hua, L. Shuzhuo, W. Yukuan, M. Feldman, P. Kareiva, S. Polasky, et al. 2013. Securing natural capital and human well-being: Innovation and impact in China. Ecology 33: 677-685. (in Chinese).

Evaluation of WLE. 2016. CGIAR independent evaluation arrangement. http://iea.cgiar.org/sites/default/files/WLE\%20Evaluation\% 20Report\%20Volume\%20I.pdf.

FAO. 2011a. Global food losses and food waste-Extent, causes and prevention. Rome: Food and Agriculture Organization of the United Nations.

FAO. 2011b. Save and grow. A policymaker's guide to the sustainable intensification of smallholder crop production. Rome: Food and Agriculture Organization of the United Nations.

FAO. 2012. Smallholders and family farmers. Sustainability pathways, factsheet. http://www.fao.org/fileadmin/templates/nr/ sustainability_pathways/docs/Factsheet_SMALLHOLDERS. pdf.

FAO. 2013a. FAO statistical yearbook 2013. Part 1-The setting. Rome: Food and Agriculture Organization of the United Nations. http://www.fao.org/docrep/018/i3107e/i3107e01.pdf.

FAO. 2013b. Resilient livelihoods-Disaster risk reduction for food and nutrition security framework programme. Rome: Food and Agriculture Organization of the United Nations.

FAO. 2014. Building a common vision for sustainable food and agriculture: Principles and approaches. Rome: Food and Agriculture Organization of the United Nations. 
FAO, IFAD and WFP. 2013. The state of food insecurity in the world 2013. The multiple dimensions of food security. Rome: Food and Agriculture Organization of the United Nations.

Fischer, J., A.D. Manning, W. Steffen, et al. 2007. Mind the sustainability gap. Trends in Ecology \& Evolution 22: 621-624.

Fischer, J., B. Brosi, G.C. Daily, P.R. Ehrlich, R. Goldman, J. Goldstein, D.B. Lindenmayer, A.D. Manning, H.A. Mooney, L. Pejchar, J. Ranganathan, and T. Tallis. 2008. Should agricultural policies encourage land sparing or wildlife-friendly farming? Frontiers Ecology Environment 6: 380-385.

Foley, J.A., R. DeFries, G.P. Asner, C. Barford, G. Bonan, S.R. Carpenter, F.S. Chapin, M.T. Coe, et al. 2005. Global consequences of land use. Science 309: 570-574.

Foley, J.A., N. Ramankutty, K.A. Brauman, E.S. Cassidy, J.S. Gerber, M. Johnston, N.D. Mueller, C. O’Connell, et al. 2011. Solutions for a cultivated planet. Nature 478: 337-342.

Folke, C., T. Hahn, P. Olsson, and J. Norberg. 2005. Adaptive governance of social-ecological systems. Annual Review of Environment and Resources 30: 441-473.

Galloway, J.N., and E.B. Cowling. 2002. Reactive nitrogen and the world: 200 Years of change. Ambio 31: 64-71.

Garnett, T., and C.J. Godfray. 2012. Sustainable intensification in agriculture. Navigating a course through competing food system priorities. Food Climate Research Network and the Oxford Martin Programme on the Future of Food, University of Oxford.

Garnett, T., M.C. Appleby, A. Balmford, I.J. Bateman, T.G. Benton, P. Bloomer, B. Burlingame, M. Dawkins, et al. 2013. Sustainable intensification in agriculture: Premises and policies. Science 341: 33-34.

Gerland, P., A.E. Raftery, H. Ševčíková, N. Li, D. Gu, T. Spoorenberg, L. Alkema, B.K. Fosdick, et al. 2014. World population stabilization unlikely this century. Science 346: 234-237.

Godfray, H.C.J., and T. Garnett. 2014. Food security and sustainable intensification. Philosophical Transactions of the Royal Society B 369: 20120273. doi:10.1098/rstb.2012.0273.

Godfray, H.C.J., J.R. Beddington, I.R. Crute, L. Haddad, D. Lawrence, J.F. Muir, J. Pretty, S. Robinson, et al. 2010. Food security: The challenge of feeding 9 billion people. Science 327: 812-818.

Gordon, L.J., G.D. Peterson, and E.M. Bennett. 2008. Agricultural modifications of hydrological flows create ecological surprises. Trends in Ecology \& Evolution 23: 211-219.

Gruber, N., and J.N. Galloway. 2008. An earth-system perspective of the global nitrogen cycle. Nature 451: 293-296.

IAASTD. 2008. Agriculture at a crossroads: The synthesis report. Synthesis report with executive summary: A synthesis of the global and sub-global IAASTD reports. International Assessment of Agricultural Knowledge, Science and Technology for Development (IAASTD). Washington, DC: Island Press.

IFPRI. 2015. Global nutrition report 2015: Actions and accountability to advance nutrition and sustainable development. Washington, DC: International Food Policy Research Institute.

IPCC. 2014. Climate change 2014: Impacts, adaptation, and vulnerability. In Part A: Global and sectoral aspects. Contribution of working group II to the fifth assessment report of the intergovernmental panel on climate change, ed. C.B. Field, V.R. Barros, D.J. Dokken, K.J. Mach, M.D. Mastrandrea, T.E. Bilir, M. Chatterjee, K.L. Ebi, Y.O. Estrada, R.C. Genova, B. Girma, E.S. Kissel, A.N. Levy, S. MacCracken, P.R. Mastrandrea, and L.L. White. Cambridge, New York: Cambridge University Press.

Jackson, L.E., M.M. Pulleman, L. Brussaard, K.S. Bawa, G.G. Brown, I.M. Cardoso, P.C. de Ruiter, L. Garcia-Barrios, et al. 2012. Social-ecological and regional adaptation of agrobiodiversity management across a global set of research regions. Global Environmental Change 22: 623-639.
Kabat, P. 2013. Water at a crossroads. Nature Climate Change 3: $11-12$.

Keating, B.A., M. Herrero, P.S. Carberry, J. Gardner, and M.B. Cole. 2014. Food wedges: Framing the global food demand and supply challenge towards 2050. Global Food Security 3: 125-132.

Kuyper, T.W., and P.C. Struik. 2014. Epilogue: Global food security, rhetoric, and the sustainable intensification debate. Current Opinion in Environmental Sustainability 8: 71-79.

Kulkarni, H., and M. Shah. 2013. Punjab water syndrome. Diagnostics and prescriptions. Review of rural affairs. Economic \& Political Weekly XLVIII 52: 64-73.

Law, E.A., E. Meijaard, B.A. Bryan, T. Mallawaarachchi, L.P. Koh, and K.A. Wilson. 2015. Better land-use allocation outperforms land sparing and land sharing approaches to conservation in Central Kalimantan, Indonesia. Biological Conservation 186: 276-286.

Lenton, T.M., H. Held, E. Kriegler, J.W. Hall, W. Lucht, S. Rahmstorf, and H.J. Schellnhuber. 2008. Tipping elements in the Earth's climate system. Proceedings of the National Academy of Sciences of the United States of America 105: 1786-1793.

Le Quéré, C., R. Moriarty, R.M. Andrew, J.G. Canadell, S. Sitch, J.I. Korsbakken, P. Friedlingstein, G.P. Peters, et al. 2015. Global carbon budget 2015. Earth System Science Data 7: 349-396. doi:10.5194/essd-7-349-2015.

Liniger, H.P., R. Mekdaschi Studer, C. Hauert, and M. Gurtner. 2011. Sustainable land management in practice-Guidelines and best practices for Sub-Saharan Africa. TerrAfrica, World Overview of Conservation Approaches and Technologies (WOCAT) and Food and Agriculture Organization of the United Nations (FAO).

Ministry of Environmental Protection of China, Chinese Academy of Sciences. National Ecosystem Service Zoning in China. 1998. (in Chinese).

NDRC (National Development and Reform Commission). Opinions on accelerating the construction of ecological civilization. National Development and Reform Commission of People's Republic of China, Beijing, 2013.

Ouyang, Z., C. Zhu, G. Yang, X. Weihua, H. Zheng, Y. Zhang, and Yi Xiao. 2013. Gross ecosystem product concept accounting framework and case study. Acta Ecologica Sinica 33: 6747-6761. (in Chinese).

Pardey, P.G., J.M. Beddow, T.M. Hurley, T.K.M. Beatty, and V.R. Eidman. 2014. A bounds analysis of world food futures: Global agriculture through to 2050. Australian Journal of Agricultural and Resource Economics 58: 571-589.

Phalan, B., M. Onial, A. Balmford, and R.E. Green. 2011. Reconciling food production and biodiversity conservation: Land sharing and land sparing compared. Science 333: 1289-1291.

Ponisio, L.C., L.K. M'Gonigle, K.C. Mace, J. Palomino, P. de Valpine, and C. Kremen. 2015. Diversification practices reduce organic to conventional yield gap. Proceedings of the Royal Society B 282: 20141396. doi:10.1098/rspb.2014.1396.

Pretty, J. 2008. Agricultural sustainability: Concepts, principles and evidence. Philosophical Transactions of the Royal Society B 363: 447-466.

Pretty, J.N., A.D. Noble, D. Bossio, J. Dixon, R.E. Hine, F.W.T. Penning de Vries, and J.I.L. Morison. 2006. Resource-conserving agriculture increases yields in developing countries. Environmental Science and Technology 40: 1114-1119.

Pretty, J.N., C. Toulmin, and S. Williams. 2011. Sustainable intensification in African agriculture. International Journal of Agricultural Sustainability 9: 5-24.

Poppy, G.M., S. Chiotha, F. Eigenbrod, C.A. Harvey, M. Honzák, M.D. Hudson, A. Jarvis, N.J. Madise, et al. 2014. Food security in a perfect storm: Using the ecosystem services framework to increase understanding. Philosophical Transactions of the Royal Society B 369: 20120288. doi:10.1098/rstb.2012.0288. 
Ramankutty, N., A.T. Evan, C. Monfreda, and J.A. Foley. 2008. Farming the planet: 1. Geographic distribution of global agricultural lands in the year 2000. Global Biogeochemical Cycles 22: GB1003. 10.1029/2007GB002952.

Ray, D.K., N.D. Mueller, P.C. West, and J.A. Foley. 2013. Yield trends are insufficient to double global crop production by 2050 . PLoS One 8: e66428. doi:10.1371/journal.pone.0066428.

Reij, C., G. Tappan, and M. Smale. 2009. Agroenvironmental Transformation in the Sahel: Another Kind of "Green Revolution", p. 43. International Food Policy Research Institute (IFPRI), IFPRI discussion paper 00914, Washington, DC.

Rockström, J., and L. Karlberg. 2010. The quadruple squeeze: Defining the safe operating space for freshwater use to achieve a triply green revolution in the Anthropocene. Ambio 39: 257-265.

Rockström, J., W. Steffen, K. Noone, A. Persson, F.S. Chapin III, E. Lambin, T.M. Lenton, M. Scheffer, et al. 2009. A safe operating space for humanity. Nature 461: 472-475.

Rockström, J., M. Falkenmark, T. Allan, C. Folke, L. Gordon, A. Jägerskog, M. Kummu, M. Lannerstad, et al. 2014. The unfolding water drama in the Anthropocene: Towards a resilience-based perspective on water for global sustainability. Ecohydrology 7: 1249-1261.

Rogelj, J., G. Luderer, R.C. Pietzcker, E. Kriegler, M. Schaeffer, V. Krey, and K. Riahi. 2015. Energy system transformations for limiting end-of-century warming to below $1.5^{\circ} \mathrm{C}$. Nature Climate Change 5: 519-528.

Royal Society. 2009. Reaping the benefits: Science and the sustainable intensification of global agriculture. London: Royal Society.

Shah, M. 2013. Water: Towards a paradigm shift in the twelfth plan. Economic and Political Weekly 48: 41.

Steffen, W., P.J. Crutzen, and J.R. McNeill. 2007. The Anthropocene: Are humans now overwhelming the great forces of nature? Ambio 36: 614-621.

Steffen, W., A. Persson, L. Deutsch, J. Zalasiewicz, M. Williams, K. Richardson, C. Crumley, P. Crutzen, et al. 2011. The Anthropocene: From global change to planetary stewardship. Ambio 40: 739-761.

Steffen, W., K. Richardson, J. Rockström, S.E. Cornell, I. Fetzer, E.M. Bennett, R. Biggs, S.R. Carpenter, et al. 2015a. Planetary boundaries: Guiding human development on a changing planet. Science 347: 736-747.

Steffen, W., W. Broadgate, L. Deutsch, O. Gaffney, and C. Ludwig. 2015b. The trajectory of the Anthropocene: The great acceleration. The Anthropocene Review. doi:10.1177/2053019614564785.

Struik, P.C., T.W. Kuyper, L. Brussaard, and C. Leeuwis. 2014. Deconstructing and unpacking scientific controversies in intensification and sustainability: Why the tensions in concepts and values? Current Opinion in Environmental Sustainability 8: 80-88.

The State Council of China. The main functional area planning of China. 2010. (in Chinese).

Tilman, D., and M. Clark. 2014. Global diets link environmental sustainability and human health. Nature 515: 518-522.

Tilman, D., C. Balzer, J. Hill, and B.L. Befort. 2011. Global food demand and the sustainable intensification of agriculture. Proceedings of the National Academy of Sciences of the United States of America 108: 20260-20264.

Tilman, D., J. Fargione, B. Wolff, C. D'Antonio, A. Dobson, R. Howarth, D. Schindler, W.H. Schlesinger, et al. 2001. Forecasting agriculturally driven global environmental change. Science 292: 281-284.

Tittonell, P. 2014. Ecological intensification of agriculture-Sustainable by nature. Current Opinion in Environmental Sustainability 8: 53-61.

Tscharntke, T., Y. Clough, T.C. Wanger, L. Jackson, I. Motzke, I. Perfecto, J. Vandermeer, and A. Whitbread. 2012. Global food security, biodiversity conservation and the future of agricultural intensification. Biological Conservation 151: $53-59$.

United Nations Environment Programme (UNEP). 2014. Assessing global land use: Balancing consumption with sustainable supply. A Report of the Working Group on Land and Soils of the International Resource Panel. Bringezu S., Schütz H., Pengue W., ÓBrien M., Garcia F., Sims R., Howarth R., Kauppi L., Swilling M., and Herrick J.

United Nations Secretary-General's High-level Panel on Global Sustainability (UN GSP). 2012. Resilient people, resilient planet: A future worth choosing. Report for the 2012 Rio + 20 Earth summit, New York.

van Noordwijk, M., and L. Brussaard. 2014. Minimizing the ecological footprint of food: Closing yield and efficiency gaps simultaneously? Current Opinion in Environmental Sustainability 8: 62-70.

Waters, C.N., J. Zalasiewicz, and C. Summerhayes, et al. 2016. The Anthropocene is functionally and stratigraphically distinct from the Holocene. Science 351(6229): aad2622-1-10.

Williams, J., and F. McKenzie. 2008a. 'Agriculture'. In 10 Commitments: Reshaping the lucky country's environment, ed. D.B. Lindenmayer, S. Dovers, M. Harriss Olson, and S. Morton, 105-112. Melbourne: CSIRO Publishing.

Williams, J., and F. McKenzie. 2008b. Farming without Harming. Australasian Science 29: 31-34.

World Bank. 2007. World Development Report 2008: Agriculture for Development. Washington, DC.

World Bank. 2010. Deep wells and prudence: towards pragmatic action for addressing groundwater overexploitation in India.

WRI (World Resources Institute). 2013. Creating sustainable food futures: a menu of solutions to sustainably feeding more than 9 billion people by 2050. Chapter 4. World Resources Report 2013-02014: Interim Findings (p. 144). Washington.

\section{AUTHOR BIOGRAPHIES}

Johan Rockström $(\square)$ is a Professor at Stockholm Resilience Centre. His interdisciplinary research interests are on global water resources, ecosystem services, agricultural development, social-ecological resilience and Earth system research.

Address: Stockholm Resilience Centre, Stockholm University, Stockholm, Sweden.

e-mail: johan.rockstrom@su.se

John Williams, FTSE, is an Adjunct Professor at Crawford School of the Australian National University and the Institute of Land Water and Society of Charles Sturt University. His research interests lay focus on development of sustainable food and fiber production and its impact on natural resources and the environment.

Address: Crawford School of Public Policy, Australian National University, Canberra, Australia.

e-mail: jwi13940@bigpond.net.au

Gretchen Daily is a Professor at the Department of Biology, Stanford University. Her research interests include sustainable agricultural systems, harmonizing conservation of biodiversity and ecosystem services with rural livelihoods.

Address: Department of Biology, Stanford University, Stanford, USA. e-mail: gdaily@stanford.edu

Andrew Noble is a Deputy Director General Research at International Centre for Agriculture Research in the Dry Areas (ICARDA). His research interests include degraded production systems.

Address: ICARDA, Amman, Jordan.

e-mail: a.noble@cgiar.org 
Nathanial Matthews is the Research Coordinator at the CGIAR Research Program on Water, Land and Ecosystems. His research interests include political ecology and political economy of natural resource management.

Address: CGIAR Research Program on Water, Land and Ecosystems, Battaramulla, Sri Lanka.

e-mail: n.matthews@cgiar.org

Line Gordon is an Assistant Professor at the Stockholm Resilience Centre. Her research focuses on freshwater resources, ecosystem services and food production.

Address: Stockholm Resilience Centre, Stockholm University, Stockholm, Sweden.

e-mail: line.gordon@su.se

Hanna Wetterstrand is a $\mathrm{PhD}$ candidate and a program officer at Stockholm Resilience Centre at Stockholm University. Her research interests include global food security and deliberative methods in valuing ecosystem services.

Address: Stockholm Resilience Centre, Stockholm University, Stockholm, Sweden.

e-mail: hanna.wetterstrand@su.se

Fabrice DeClerck is an Associate Professor and a community and landscape ecologist trained at the University of California Davis. He currently works for Bioversity International, a member center of the CGIAR charged with research for development on the contribution of biodiversity of ecosystem services in agricultural development. His research covers several domains of biodiversity's impacts from human health and nutrition, to agro-ecological services such as pollination and pest control, and landscape planning for the sustainable management of common-pool ecosystem services.

Address: Bioversity International, Montpellier, France.

e-mail: f.declerk@cgiar.org

Mihir Shah is President of Bharat Rural Livelihoods Foundation and a Visiting Professor of Political Economy at Ashoka University. His research interests include ecological economics, sustainable livelihoods and participatory water management.

Address: Bharat Rural Livelihoods Foundation, New Delhi, India. e-mail:mihir.shah@nic.in

Pasquale Steduto is an FAO Representative in Egypt. His research interests include agricultural water use efficiency and water productivity, focusing on crops' yield response to water and associated modeling development under water-scarce conditions.

Address: FAO, Land and Water Division, Rome, Italy. e-mail: pasquale.steduto@fao.org
Charlotte de Fraiture is a Professor of Land and Water Development at UNESCO-IHE, Centre for Water Education based in Delft, The Netherlands. Her research interests include sustainable use of water for agriculture, water for food security, irrigation and drainage. Address: Unesco-IHE, Delft, The Netherlands.

e-mail: c.defraiture@unesco-ihe.org

Nuhu Hatibu is a Professor and CEO of Kilimo Trust. His research interests include agricultural value chains, knowledge management, strategy formulation, and capacity building and management of water for agriculture.

Address: Kilimo Trust, Kampala, Uganda.

e-mail: nuhu.hatibu@kilimotrust.org

Olcay Unver is the Deputy Director of Land and Water Division of the Food and Agriculture Organization of the United Nations (FAO) since September 2013. His professional interests include water within a socioeconomic development context, transboundary water cooperation, water governance, and natural resources management.

Address: FAO, Land and Water Division, Rome, Italy.

e-mail: olcay.unver@fao.org

Jeremy Bird specializes in water resources policy, management and institutions and joined IWMI in October 2012 having been CEO of the Mekong River Commission for three years. His varied career includes research and consultancy work across Asia and Africa and experience with project development with the Asian Development Bank. His research interests include water law and policy, water resources institutions and management, and dams and hydropower. Address: IWMI, Battaramulla, Sri Lanka.

e-mail: j.bird@cgiar.org

Lindiwe Sibanda, FANRPAN South Africa, is currently the CEO of the Food, Agriculture and Natural Resources Policy Analysis Network (FANRPAN). Under her leadership, FANRPAN was transformed from a small sub-regional network to a global player in the food security agenda giving voice to Africa's position on the Green Revolution, Climate Smart Agriculture and Nutrition Sensitive Agriculture.

Address: FANRPAN, Pretoria, South Africa.

e-mail: 1msibanda@fanrpan.org

Jimmy Smith, Ph.D., is a Director General of the International Livestock Research Institute (ILRI) at Animal sciences, Global Livestock.

Address: ILRI, Nairobi, Kenya.

e-mail: j.smith@cgiar.org 